\title{
Profil Pasien Suspek Koinfeksi TB pada HIV di Rumah Sakit Penyakit Infeksi (RSPI) Prof. Dr. Sulianti Saroso Tahun 2015
}

\author{
Profile Suspected TB-HIV Patients in Infectious Disease Hospital Prof. Dr. \\ Sulianti Saroso 2015
}

\author{
Rosamarlina*, Farida Murtiani, Tri Yuli Setianingsih, Debby Permatasari \\ Rumah Sakit Penyakit Infeksi (RSPI) Prof. Dr. Sulianti Saroso
}

*Korespondensi Penulis :

dr. Rosamarlina, Sp.P

Email : rosa_pulmo@yahoo.com

\begin{abstract}
Abstrak
Latar belakang : Dampak pandemi Human Immunodefiency Virus (HIV) di dunia akan menambah permasalahan Tuberkulosis (TB). Koinfeksi TB dengan HIV merupakan tantangan besar dalam program pengendalian kedua penyakit tersebut. Kedua penyakit ini dan penyebabnya dapat saling berinteraksi dan mempengaruhi epidemiologi masing-masing. Maka diperlukan beberapa penelitian untuk mengetahui besarnya angka kejadian koinfeksi TB-HIV dan juga profil dari pasien koinfeksi TB-HIV.

Metode : Penelitian ini adalah penelitian diskriptif dengan desain potong lintang. Pengambilan data primer dengan instrument Case Report Form (CFR) dilakukan selama 3 bulan sejak September - November 2015. Sampel dalam penelitian ini adalah pasien suspek TB pada HIV dan HIV non TB sebanyak 38 pasien yang memenuhi kriteria inklusi dan eksklusi.

Hasil : Jumlah pasien HIV pada periode September - November 2015 hanya 10 pasien yang TB-HIV. Dari 38 pasien suspek TB-HIV sebagian besar berusia $\leq 35$ tahun $(52,6 \%)$ dan berjenis kelamin laki-laki $(73,7 \%)$, menunjukkan Gejala klinis pasien suspek TB-HIV terbanyak adalah demam (94.7\%), batuk $(100 \%)$, batuk berdahak $(89,5 \%)$, berkeringat malam hari $(86,8 \%)$, mudah lelah $(97,4 \%)$, gangguan tidur $(86,8 \%)$, berat badan turun $(100 \%)$, infeksi opportunistik candidiasis oral $(60.5 \%)$ dengan hasil foto rontgen terbanyak yaitu Tb Paru (44,7\%). Hasil apusan sputum pertama $84,2 \%$ BTA negative, apusan kedua $76,3 \%$ BTA negative dan apusan ketiga 86,8\% BTA negative. Gambaran CD4 pada pasien TB-HIV $73,7 \%$ dengan CD4 < $100 \mathrm{sel} / \mathrm{mm}^{3}$.

Kesimpulan : Sulit menentukan pasien koinfeksi TB pada pasien HIV tanpa dilengkapi pemeriksaan penunjang Foto Rontgen dan pemeriksaan CD4.
\end{abstract}

Kata kunci : Pofil pasien, Suspek, TB-HIV

\begin{abstract}
Background: Impact of Human Immunodefiency Virus (HIV) pandemic in the world will add to the problems of tuberculosis (TB). TB co-infection with HIV is a major challenge in controlling both diseases program. Both of these diseases and their causes can interact and affect each epidemiology. So it takes some research to determine the incidence of TB-HIV co-infection and also the profile of TB-HIV co-infected patients.

Methods: This research is a descriptive study with cross-sectional design. Primary data with the instrument Case Report Form (CFR) was conducted for 3 months from September to November 2015. The sample in this study are patients with suspected TB in HIV and non HIV-TB in 38 patients who met the criteria of inclusion and exclusion.

Results: The number of HIV patients in the period from September to November, 2015 only 10 patients with TB-HIV. Of the 38 patients with suspected TB-HIV mostly aged <35 years (52.6\%) and male sex (73.7\%) showed clinical symptoms of patients with suspected TB-HIV most was fever (94.7\%), cough (100\%), cough with phlegm (89.5\%), night sweats (86.8\%), fatigue (97.4\%), sleep disorders (86.8\%), weight loss (100\%), infection opportunistic oral candidiasis (60.5\%) with the results of $x$-rays that most pulmonary tuberculosis (44.7\%). The results of the first sputum smear (84.\%) with result negative, the second sputum smear (76.\%) with result negative and and the third sputum smear (86.8\%) with result negative. Overview CD4 TB-HIV patients is $73.7 \%$ with CD4 $<100$ cells / mm3.
\end{abstract}


Conclusion: Difficult to determine which patients TB co-infection in HIV patients without investigation include $X$-rays and CD4.

Keywords : Patient profil, Suspect, TB-HIV

\section{Pendahuluan}

Dampak pandemi HIV di dunia akan menambah permasalahan TB. koinfeksi TB dengan HIV merupakan tantangan besar dalam program pengendalian kedua penyakit tersebut. WHO memperkirakan pada tahun 2014 terdapat 9,6 juta orang di seluruh dunia menderita TB. ODHA dengan TB laten berisiko 26 kali (24-28) untuk menjadi pasien dengan TB aktif. $^{1}$ Perkiraan WHO tentang jumlah pasien TB dengan status HIV positif di Indonesia pada tahun 2013 sekitar 7,5\% yang meningkat cukup signifikan dibandingkan tahun 2012 yang hanya 3,3\%. ${ }^{2}$ TB masih dilaporkan sebagai sebagai infeksi oportunistik (IO) terbanyak pada ODHA yaitu sebesar 49\% pada tahun 2010, meskipun persentasinya sedikit menurun pada tahun 2013 menjadi 39,48\% dari seluruh koinfeksi dan pada tahun 2014 (sampai akhir September) sebanyak 28,04\%. ${ }^{3,4}$ Jumlah kematian TB yang terkait HIV meskipun telah menurun sejak tahun 2004 yang diperkirakan sekitar 540.000, namun secara global masih tercatat sekitar 360.000 pada akhir tahun 2013, setara 25\% dari seluruh kematian TB dan sekitar $25 \%$ dari perkiraan 1,5 juta kematian akibat HIV/AIDS. ${ }^{5}$

Penelitian di Tanzania membuktikan bahwa pada kelompok pengidap HIV dengan TB akan 4.7 kali (95\% Cl : 1.63-13.05) lebih cepat untuk mengalami kematian di bandingkan dengan kelompok pengidap HIV tanpa $\mathrm{TB}^{6} \quad$ TB merupakan penyebab kematian pada $39.3 \%$ pasien koinfeksi TB-HIV yang menjalani pengobatan di Thailand. $^{7}$ Penelitian di Indonesia mendapatkan hazard ratio yang lebih kecil dimana pasien HIV/AIDS dengan TB hanya $1.6(95 \% \mathrm{Cl}$ : 0.96-2.67) kali lebih cepat untuk mengalami kematian dibandingkan pasien HIV/AIDS tanpa $\mathrm{TB}^{8}$

Berdasarkan keputusan Menteri Kesehatan Republik Indonesia Nomor 451/MENKES/SK/XII/2012, Rumah Sakit Penyakit Infeksi (RSPI) Prof. Dr. Sulianti Saroso merupakan salah satu rumah sakit rujukan bagi ODHA. Berdasarkan laporan rutin POKJA HIVAIDS di RSPI Sulianti Saroso per Desember 2014, jumlah ODHA diperkirakan mencapai 4550 orang dengan 1700 diantaranya merupakan pasien ko-infeksi TB-HIV. Pasien koinfeksi TB-HIV yang belum pernah 
mendapat pengobatan ARV pada tahun 2011 hingga 2014 secara berurutan yang tercatat sebanyak 133, 136, 184, dan 120 pasien. $^{9}$

Banyak faktor dari pasien yang memungkinkan berhubungan dengan tingginya angka koinfeksi TB-HIV dan memunculkan karakteristik tertentu untuk pasien koinfeksi TB-HIV. Maka diperlukan beberapa penelitian untuk mengetahui besarnya angka kejadian koinfeksi TB-HIV dan juga profil dari pasien ko infeksi TB-HIV. Penelitian ini bertujuan untuk mengetahui karakteristik pasien, gejala klinis, hasil pemeriksaaan sputum BTA, gambaran foto thoraks, dan hasil laboratorium pasien koinfeksi TB-HIV di RSPI Prof. Dr. Sulianti Saroso sejak September November 2015.

\section{Metode}

Penelitian ini adalah diskriptif
dengan desain potong lintang.
Pengambilan data primer dengan instrument Case Report Form (CFR) dilakukan selama 3 bulan sejak September - November 2015. Sampel diambil dari rawat jalan yaitu poli DOTS dan Poli Paru RSPI Prof. Dr. Sulianti Saroso.

Sampel adalah pasien suspek TB pada HIV. Kriteria inklusi subyek positif HIV berdasarkan hasil test HIV, gejala klinis riwayat episodik demam ditambah gejala batuk atau penurunan berat badan yang signifikan dalam 2 bulan tanpa alasan yang jelas atau keringat malam atau diare akut atau kelelahan atau penurunan nafsu makan atau gangguan tidur, kelompok umur $>14$ tahun, semua jenis kelamin dan sukarela mengikuti penelitian dengan menandatangani lembar persetujuan setelah mendapatkan informasi lembar penjelasan. Sementara kriteria ekslusi adalah subyek HIV yang sudah minum obat TB > 1 bulan, dan wanita hamil selama penelitian.

Diagnosis TB ditegakkan berdasarkan gejala klinis, hasil pemeriksaaan sputum BTA dan gambaran foto thoraks. Diagnosis HIV ditegakkan berdasarkan metode rapid test sesuai pedoman pelayanan testing HIV/AIDS Depertemen Kesehatan Republik Indonesia. Penelitian ini telah mendapatkan ethical clearance dari Komisi Etik Badan Penelitian dan Pengembangan Kesehatan No.LB.02.01/5.2/KE.177/2015. Analisa data dilakukan secara univariat.

\section{Hasil}

Sampel dalam penelitian ini sebanyak 38 pasien HIV suspek TB dan non TB yang diambil dari poli DOTS dan poli paru selama 3 bulan sejak September - November 2015. Dari 38 pasien tersebut diketahui bahwa hanya 10 pasien yang positif TB-HIV dan 28 yang non TB-HIV. 
Sebagian besar berusia $\leq 35$ tahun yaitu $20(52,6 \%)$ dan berjenis kelamin laki-laki yaitu $28(73,7 \%)$ terlihat pada table 1.

Tabel 1. Karakteristik Pasien dan Hasil Kultur Suspek Koinfeksi TB-HIV

\begin{tabular}{lcc}
\hline Variabel & $\mathrm{n}$ & $\begin{array}{c}\text { Persentase } \\
(\%)\end{array}$ \\
\hline Karakteristik & & \\
Umur (tahun) & & \\
- $\quad>35$ Tahun & 18 & 47,4 \\
- $\quad \leq 35$ Tahun & 20 & 52,6 \\
Jenis Kelamin & & \\
- Laki-laki & 28 & 73,7 \\
- Perempuan & 10 & 26,3 \\
Hasil Kultur & & \\
- Positif & 10 & 26,3 \\
- Nagatif & 28 & 73,7 \\
\hline
\end{tabular}

Gejala klinis pasien suspek TBHIV terbanyak adalah demam (94.7\%), batuk (100\%), batuk berdahak $(89,5 \%)$, berkeringat malam hari $(86,8 \%)$, mudah lelah $(97,4 \%)$, gangguan tidur $(86,8 \%)$, berat badan turun (100\%) $23(60.5 \%)$ candidiasis oral dengan hasil foto rontgen terbanyak yaitu $\mathrm{Tb}$ Paru $(44,7 \%)$ seperti terlihat pada tabel 2.

Hasil apusan sputum pertama sebanyak 32 pasien (84,2\%) BTA negative, apusan kedua 29 (76,3\%) BTA negative dan apusan ketiga 33 $(86,8 \%)$ BTA negative (Gambar 1$)$.
Tabel 2. Gambaran Gejala Klinis dan Hasil Foto Rontgen Pasien Suspek Koinfeksi TB-HIV

\begin{tabular}{|c|c|c|}
\hline Variabel & $\mathrm{n}$ & $\begin{array}{c}\text { Persentase } \\
(\%)\end{array}$ \\
\hline \multicolumn{3}{|l|}{ Gejala Klinis } \\
\hline Deman & 36 & 94,7 \\
\hline Batuk & 38 & 100 \\
\hline Batuk berdahak & 34 & 89,5 \\
\hline Berkeringat malam hari & 33 & 86.8 \\
\hline Mudah lelah & 37 & 97,4 \\
\hline Gangguan tidur & 33 & 86,8 \\
\hline Sesak nafas & 19 & 50 \\
\hline Diare & 21 & 55,3 \\
\hline Berat badan turun & 38 & 100 \\
\hline Tidak nafsu makan & 13 & 34,2 \\
\hline Muntah & 7 & 21,1 \\
\hline Mual & 8 & 21,1 \\
\hline Nyeri dada & 2 & 5,3 \\
\hline Pusing & 8 & 21,2 \\
\hline Candidiasis oral & 23 & 60,5 \\
\hline KGB & 11 & 28,9 \\
\hline PPE & 5 & 13,2 \\
\hline \multicolumn{3}{|l|}{ Hasil Rontgen } \\
\hline Normal & 4 & 10,5 \\
\hline Suspek Tb Paru & 8 & 21,1 \\
\hline Tb Paru & 17 & 44,7 \\
\hline Tb Paru DD BP & 1 & 2,6 \\
\hline Bronkhopneumonia & 1 & 2,6 \\
\hline Pleuritis ex TB & 1 & 2,6 \\
\hline Tb Paru perbaikan & 5 & 13,2 \\
\hline TB Paru perburukan & 1 & 2,6 \\
\hline
\end{tabular}




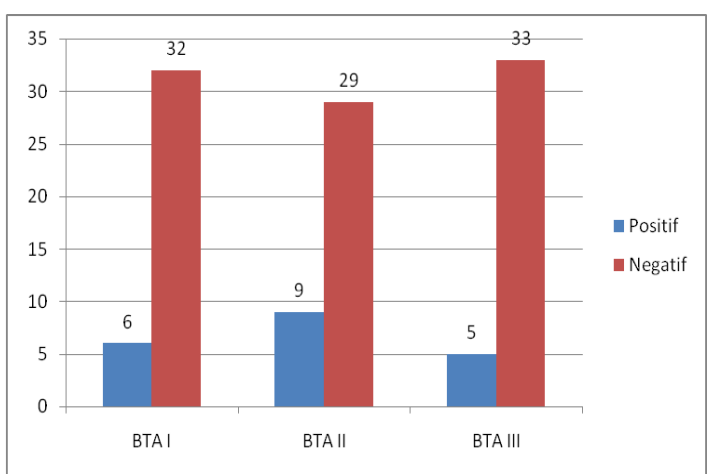

Gambar 1 Apusan Sputum Pasien Suspek Koinfeksi TB-HIV

Gambaran CD4 pada pasien TBHIV sebagian besar yaitu 28 (73,7\%) dengan CD4 < $100 \mathrm{sel} / \mathrm{mm}^{3}$ terlihat pada gambar 2 .

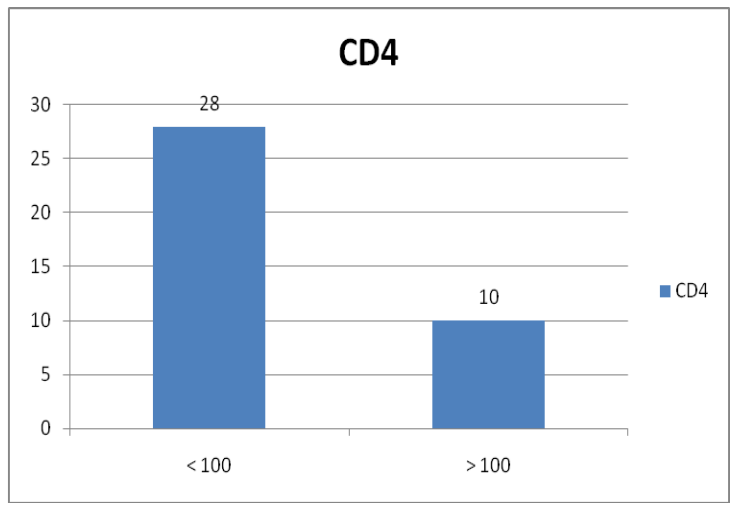

Gambar 2. Jumlah CD4 Pasien Suspek Koinfeksi TB-HIV

\section{Pembahasan}

Pada periode September November 2015 dari 38 pasien HIV hanya sebanyak 10 pasien yang positif TB-HIV. Penelitian ini didapatkan hasil persentase terbanyak pasien suspek koinfeksi TB-HIV adalah lelaki 73,7\%. Hal ini sesuai dengan penelitian Soraya dan Artika di RSUP Sanglah pada tahun 2013 dengan hasil presentase lelaki mencapai $77,7 \% .^{10}$ Hasil penelitian Dessy Ayu Permitasari di RSUP dr. Kariadi Semarang pada tahun 2012 dengan hasil presentase lelaki lebih banyak mencapai $71.1 \%{ }^{11}$

Usia suspek koinfeksi TB-HIV adalah $\leq 35$ Tahun (52,6\%) usia termuda 20 Tahun dan tertua 55 Tahun. Penelitian Soraya dan Artika di RSUP Sanglah menyatakan pasien TBHIV lebih banyak ditemukan pada pasien 15-35 tahun sebesar 15 orang $(55.5 \%)$ dibandingkan pada usia > 35 tahun yaitu 12 orang (44.5\%). 10 Penelitian Dessy Ayu Permitasari di RSUP dr. Kariadi Semarang usia yang mempunyai angka tertinggi adalah 1535 tahun. $^{11}$

Gejala klinis yang banyak dirasakan seluruh pasien suspek koinfeksi TB-HIV adalah demam,batuk, batuk berdahak, berkeringat malam hari, mudah lelah, gangguan tidur, dan berat badan turun. Gejala klinis klasik pada TB paru tampak pad pasein imunokompromis yang tidak berat (CD4 $\left.>200 / \mathrm{mm}^{3}\right) .{ }^{12}$ Penurunan CD4 ini dapat mengubah gambaran klinis TB, TB dengan CD4 yang rendah dihubungkan dengan gejala klinis sistemik seperti demam, lemah dan lesu. ${ }^{13}$

Penelitian Sharma et all menyatakan penurunan berat badan sangat umum pada pasien TB-HIV. Keadaan tersebut disebut slim disease. Penurunan berat badan ini diperkirakan 
berkaitan dengan diare kronik akibat enteropati HIV. ${ }^{14}$

Candidiasis oral merupakan infeksi opportunistik yang sering muncul pada pasien TB-HIV. Dalam penelitian ini candidiasis oral mencapai $60,5 \%$. Hal ini sejalan dengan penelitian Dessy Ayu Permatasari yang juga memperlihatkan infeksi candidiasis oral merupakan infeksi oportunistik tertinggi pada pasien TB-HIV. ${ }^{11}$ Penelitian Soraya dan Artika di RSUP Sanglah menyebutkan bahwa candidiasis oral pada pasien TB-HIV merupakan infeksi oportunistik terbanyak (66.6\%). ${ }^{10}$

Hasil apusan sputum pertama kedua dan ketiga sebagian besar negative. Sejalan dengan penelitian Amin et all, yang menyatakan bahwa pemeriksaan sputum pada pasien TBHIV mayoritas negative. ${ }^{15} \mathrm{Hal}$ Penelitian lain dilakukan oleh Ngatwanto Parto Dikromo yang menyebutkan bahwa mayoritas hasil pemeriksaan BTA adalah negative yang dikarenakan status imunitas pasien HIV Menurun. Turunnya status imunitas dapat mempengaruhi gambaran bakteriologis yang berakibat pada hasil sputum BTA negatif. ${ }^{16}$

Sensitivitas pemeriksaan sputum BTA pada pasien HIV berkisar $50 \%$ dan sensitivitasnya menurun pada imunokompromis yang berat. ${ }^{17}$ Masih adanya pasien suspek koinfeksi TBHIV dengan pemeriksaan sputum BTA dengan hasil negative, hal ini dimungkinkan dipengaruhi oleh keluhan batuk kering sehingga sulit mengeluarkan dahak.

Hasil gambaran foto rontgen sebagian besar yaitu 44,7\% TB Paru, sebaiknya diperjelas dengan ada tidaknya keterlibatan limfadenopati intralokal. Gambaran foto thorax pasien koinfeksi TB-HIV yang sering dijumpai adalah atipikal yang melibatkan lobus bawah dengan kecenderungan difus. ${ }^{18}$

Pemeriksaan foto toraks memegang peranan penting dalam membantu diagnosis TB paru pada ODHA khususnya dengan bakteriologis negatif dan ODHA yang tidak dapat mengeluarkan dahak setelah dilakukan berbagai upaya untuk menginduksi dahak. Foto toraks tidak selalu memberikan gambaran yang spesifik untuk TB paru pada ODHA sehingga dapat menyebabkan over-diagnosis atau under-diagnosis sehingga tidak diperkenankan untuk mendiagnosis TB paru hanya berdasarkan hasil pemeriksaan foto toraks. Pada pasien TB pada umumnya, termasuk pasien ODHA stadium awal dengan status imunitas normal, pemeriksaan foto 
toraks biasanya memberikan gambaran infiltrat yang khas di apeks lobus atas, beberapa kavitas atau efusi pleura unilateral. Namun, jika ketahanan tubuh sudah menurun drastis karena infeksi lanjut, misalnya pada ODHA dengan TB stadium lanjut, infiltrat seringkali ditemukan di lobus tengah dan bawah, bentuk milier atau infiltrat difus serta adenopati. $^{16}$

Jumlah CD4 pada pasien suspek koinfeksi TB-HIV cenderung rendah yaitu sebagian besar $73,7 \%$ dengan CD4 < $100 \mathrm{sel} / \mathrm{mm}^{3}$. Hal ini sejalan dengan penelitian di Zimbabwe dimana diperoleh hasil $72 \%$ jumlah CD4 pasien TB-HIV dibawah $200 \mathrm{sel} / \mathrm{mm}^{3}$ dengan rerata $104,5 \mathrm{sel} / \mathrm{mm}^{3} .{ }^{19}$ Keberadaan TB akan meningktakan progresifitas infeksi HIV melalui mekanisme peningkatan replikasi virus sehingga mempercepat penurunan imunitas. ${ }^{20}$

\section{Kesimpulan}

Pada penelitian ini dapat disimpulkan bahwa sulit menentukan pasien koinfeksi TB pada pasien HIV tanpa dilengkapi pemeriksaan penunjang foto rontgen dan pemeriksaan CD4 untuk itu penelitian selanjutnya perlu diadakan algoritma skrining tuberculosis.

\section{Ucapan Terima Kasih}

Penulis mengucapkan terima kasih kepada institusi RSPI Prof Dr.
Sulianti Saroso, dr. Armedy Ronny Hasugian Sub Bidang Epidemiologi Klinik Penyakit Menular Pusat Teknologi Terapan Kesehatan dan Epidemiologi Klinik Kementerian Kesehatan RI dan semua pihak yang terlibat atas konstribusi dan bantuan dalam proses pengumpulan data.

\section{Daftar Pustaka}

1. World Health Organization (WHO). Data Epidemiologi HIV [Internet]. 2015. Available from: http://www.who.int/hiv/data/epi core july2015.png

2. Kemenkes RI. Lembar Fakta Booklet Situasi Terkini Kemajuan Pengendalian Tuberkulosis. In Jakarta; 2014.

3. Kemenkes RI. Petunjuk Teknis Tata Laksana Klinis Ko-Infeksi TB-HIV. In Jakarta; 2012.

4. Kemenkes RI. Laporan Situasi Perkembangan HIV/AIDS di Indonesia. Jakarta; 2014.

5. World Health Organization (WHO). Global Tuberculosis Report. 2014.

6. Kabali C, Mtei L, Brooks DR, Waddell $R$, Bakari $M$, Matee $M$, et al. Increased mortality associated with treated active tuberculosis in HIV-infected adults in Tanzania. Tuberculosis (Edinb) [Internet]. 2013;93(4):461-6. Available from: http://www.sciencedirect. com/science/article/pii/S1472979 213000036

7. Kantipong $\mathrm{P}$, Murakami K, Moolphate S, Aung MN, Yamada $\mathrm{N}$. Causes of mortality among 
tuberculosis and HIV co-infected patients in chiang rai, northern Thailand. HIV/AIDS - Res Palliat Care. 2012;4:159-68.

8. Meilani. Pengaruh koinfeksi tuberkulosis terhadap kesintasan tiga tahun pasien HIV / AIDS yang mendapat terapi antiretroviral di Rumah Sakit penyakit infeksi Prof DR Sulianti Saroso tahun 2009-2011= Impact of tuberculosis co infection on three year survival among. Universitas Indonesia; 2011.

9. Rusli A. Laporan Pokja HIV/AIDS RSPI Prof Dr. Sulianti Saroso. Jakarta; 2015.

10. Soraya D, Artika DM .Profil Pasien Koinfeksi TB-HIV Di Rumah Sakit Umum Pusat Sanglah Bali Tahun 2013. EJURNAL Med. 2016;5(20):6671.

11. Permitasari DA. Faktor risiko terjadinya koinfeksi tuberkulosis pada pasien HIV / AIDS di RSUP dr.Kariadi Semarang Universitas Diponegoro; 2012.

12. Departemen Kesehatan RI. Kebijakan Nasional Kolaborasi TB/HIV. Jakarta; 2007.

13. Surjanto E, Subgio S Y, Reviono, Harsini M. Profil Pasien Koinfeksi Tuberkulosis - HIV di RS Moewardi Surakarta 2010 - 2011 [Internet]. Jurnal Respirologi Indonesia Vol. 32, No. 2, April 2012 85. 2011. Available from: http://webcache.googleuserconte nt.com/search?q=cache:TTGeiU 9QbhlJ:jurnalrespirologi.org/wpcontent/uploads/2012/07/jri2012-32-2-85. $p d f+\& c d=5 \& h l=$ id\&ct=clnk\&gl=id
14. Sharma SK, Mohan A, Kadhiravan T. HIV-TB coinfection: Epidemiology, diagnosis \& management. Vol. 121, Indian Journal of Medical Research. 2005. p. 550-67.

15. Amin Z, Uyainah A, Yunihastuti E, Djoerban Z. Profil Pasien TbHiv Dan Non Tb-Hiv Di RSCM. Bul Penelit Kesehat. 2013;41(4):195-9.

16. Dikromo NP, Antariksa B, Nawas A. Factors Associated to Success Tuberculosis Therapy of Co-infection TB-HIV Patients in Persahabatan Hospital , JakartaIndonesia. J Respirasi Indones. 2011;31(1):14-21.

17. Cain KP, Kanara N, Laserson KF, Vannarith C, Sameourn K, Samnang $\mathrm{K}$, et al. The epidemiology of HIV-associated tuberculosis in rural Cambodia. Int $J$ Tuberc Lung Dis. 2007;11(9):1008-13.

18. Palomiño JC, Leao S, Rotacco V. Tuberculosis 2007: From basic science to patient care [Internet]. Tuberculosis. 2007. 687 p. Available from: www.tuberculosisTextbook.com

19. Nzou C, Kambarami RA, Onyango FE, Ndhlovu CE, Chikwasha V. Clinical predictors of low CD4 count among HIVinfected pulmonary tuberculosis clients: A health facility-based survey. South African Med J. 2010;100(9):602-5.

20. Albrecht D, Altfeld M, Behrens G, Bredeek UF, Buhk T, Dickinson L, et al. HIV Medicine 2007 [Internet]. HIV Medicine. 2007. 818 p. Available from: www.HIVMedicine.com 